\title{
PENGARUH KONSENTRASI BUBUR BUAH DAN TEPUNG KEDELAI TERHADAP KARAKTERISTIK FIT BAR BLACK MULBERRY
}

\author{
Nana Sutisna Achyadi \\ Yusman Taufik \\ Darin Intan Khairunnisa

\begin{abstract}
Program Studi Teknologi Pangan, Fakultas Teknik, Universitas Pasundan, Jl. Dr.Setiabudi No 93, Bandung, 40153, Indonesia
\end{abstract} \\ E-mail : yusmantaufik@unpas.ac.id
}

\begin{abstract}
Abstrak
Tujuan penelitian ini untuk memperoleh produk pangan darurat dan diharapkan sebagai alternatif produk pangan yang memiliki kandungan gizi lengkap sehingga dapat memenuhi kebutuhan energi. Penelitian ini menggunakan rancangan percobaan faktorial 3x3 dalam rancangan acak kelompok (RAK) dalam ulangan sebanyak 3 kali, dimana faktornya meliputi : pengaruh konsentrasi bubur buah (A) yang terdiri dari tiga taraf, yaitu $\mathrm{a}_{1}(5 \%), \mathrm{a}_{2}(10 \%)$, $\mathrm{a}_{3}(15 \%)$ serta konsentrasi tepung kedelai (B) yang terdiri dari 3 taraf, yaitu $b_{1}(14 \%), b_{2}(16 \%), b_{3}(18 \%)$. Respon pada penelitian ini adalah respon kimia, yaitu kadar protein, kadar karbohidrat, dan kadar lemak. Respon fisik yaitu kekerasan. Respon organoleptik yang meliputi warna, rasa, dan tekstur dan pengujian aktivitas antioksidan pada sampel terpilih.Konsentrasi bubur buah berpengaruh nyata terhadap kadar karbohidrat, kadar protein, kadar lemak, kekerasan, rasa, dan warna. Konsentrasi tepung kedelai berpengaruh nyata terhadap kadar karbohidrat, kadar protein, kadar lemak, tekstur, dan kekerasan. Interaksi antara konsentrasi bubur buah dan tepung kedelai berpengaruh nyata terhadap kadar karbohidrat, kadar protein, kadar lemak, dan kekerasan pada fit bar black mulberry. Berdasarkan respon fisik dan respon kimia yang telah dilakukan $\mathrm{a}_{3} \mathrm{~b}_{3}$ (konsentrasi bubur buah $15 \%$ dan konsentrasi tepung kedelai $18 \%$ ) adalah prduk terpilih dengan kadar karbohidrat 43,21\%, kadar protein 11,53\%, kadar lemak 9,23\%, kekerasan 2,15 mm/sec/100 gram, dan aktivitas antioksidan sebesar 139,480 ppm (sedang).
\end{abstract}

\begin{abstract}
The purpose of this research is to determine the consentration of fruit's pulp and soy powder of fit bar black mulberry. The model of experimental design that is used in this research is Randomized Block Design (Group) RAK with 2 factors and 3 time repetitions, so it obtained 27 units of the experiment, where the factors include: the effect of the concentration of fruit's pulp (A), which consists of three levels, $a_{1}(5 \%), a_{2}(10 \%), a_{3}(15 \%)$ and concentrations of soy powder (B) consisting of 3 levels: $b_{1}(14 \%), b_{2}(16 \%), b_{3}(18 \%)$. The response in this study is chemical response, which is protein content, carbohydrate content, and fat content, physical response is hardness. Organoleptic response include color, flavor, and texture, and then antioxidant activity for selected sample. The selected sample is $\mathrm{a}_{3} \mathrm{~b}_{3}(15 \%$ fruit pulp concentration and $18 \%$ soy flour concentration), it has $43.21 \%$ of carbohydrate content, $11.53 \%$ of protein content, $9.23 \%$ of fat content, $2.15 \mathrm{~mm} / \mathrm{sec} / 100$ grams of hardness, and $139.480 \mathrm{ppm}$ of antioxidant activity (average).
\end{abstract}

Keyword: black mulberry, soy flour, fit bar

\section{Pendahuluan}

Fit bar adalah produk makanan berbentuk batang siap saji yang dibuat dari campuran bahan pangan yang diperkaya dengan nutrisi yang kemudian dibentuk menjadi bentuk padat dan kompak.

Fit bar dapat dikonsumsi sebagai makanan siap saji yang memenuhi kebutuhan energi harian manusia. Fit bar dengan penambahan buah Black Mulberry (Morus nigra) merupakan produk pangan yang memiliki berbagai kandungan gizi yang baik untuk kesehatan. Salah satu pengolahan Black Mulberry (Morus nigra) untuk meningkatkan penggunaannya yaitu dengan membuat olahan pangan, yakni fit bar. Pengolahan buah Black Mulberry (Morus nigra) dimaksudkan untuk meningkatkan nilai gizi selain dari itu pembuatan fit bar dengan penambahan buah Black Mulberry (Morus nigra) dapat digunakan untuk mengurangi penambahan bahan yang didapat secara impor dalam pembuatan fit bar pada umumnya.

Black Mulberry (Morus nigra) adalah tanaman pohon yang mempunyai nilai gizi yang sangat bagus dan mempunyai kandungan protein kasar yang tinggi yaitu 22,9-25,6\% (Anonim, 2015).

Pada bagian buah Black Mulberry (Morus nigra) terdapat cyanidin, isoquercetin, sakarida, asam linoleat, asam stearat, serta karoten. Ekstrak etanolik tanaman ini dilaporkan memiliki khasiat sebagai antikanker secara in vitro karena memiliki kandungan fitokimia seperti quercetin dan anthosianin (Kim et al., 2000; Chen et al., 2006 dalam Widiyantoro dan Pratama, 2014)

Anthosianin dilaporkan mempunyai berbagai aktivitas biologik dan secara luas digunakan sebagai 
antioksidan. Anthosianin yang terdapat dalam Morus nigra adalah sianidin 3-rutinosida dan sianidin 3glukosida (Widiyantoro dan Pratama, 2014).

Black Mulberry (Morus nigra) mengandung nutrisi penting yang dapat meningkatkan kesehatan. Nutrisi dalam Black Mulberry (Morus nigra) meliputi protein, karbohidrat, serta vitamin dan mineral seperti kalsium, fosfor, kalium, magnesium, potassium, dan serat. Tanaman Black Mulberry (Morus nigra) ini dapat menjadi alternatif sumber karbohidrat yang berpotensi untuk dijadikan bahan dalam pembuatan fit bar.

Black Mulberry (Morus nigra) digunakan dalam pembuatan fit bar tidak hanya karena kandungan karbohidrat yang tinggi, selain itu juga memiliki pigmen antosianin yang berwarna ungu sehingga dapat dijadikan pewarna alami dalam pengolahan fit bar, karena pewarna makanan tidak hanya diperoleh dari pewarna sintetis tetapi dapat dijumpai pada bahan-bahan alami seperti buah dan sayur. Sehingga fit bar yang dihasilkan memiliki kenampakan yang lebih menarik dengan adanya pigmen dari buah tersebut.

Kedelai merupakan salah satu komoditas tanaman yang memiliki kandungan protein yang cukup tinggi sebesar $40 \%$. Kandungan protein nabati sangat baik bagi pencernaan manusia, manfaat kedelai dengan kandungan protein yang tinggi membantu dalam membangun sel-sel dalam tubuh.

Konsumsi protein kedelai setiap hari dapat menurunkan resiko penyakit jantung, osteoporosis, dan menguntungkan fungsi ginjal. Kacang kedelai dapat diolah menjadi bahan setengah jadi yaitu menjadi tepung kedelai. Tepung kacang kedelai adalah bahan makanan yang biasa dikonsumsi oleh masyarakat Indonesia. Tepung kedelai mengandung energi sebesar $347 \mathrm{kkal}$, protein 35,9 gram, karbohidrat 29,9 gram, lemak 20,6 gram, kalsium $195 \mathrm{mg}$, fosfor $554 \mathrm{mg}$, dan zat besi $8 \mathrm{mg}$. Selain itu dalam tepung kedelai juga terkandung vitamin $\mathrm{A}$, vitamin $\mathrm{B} 1$, dan vitamin $\mathrm{C}$ dalam 100 gram tepung kedelai.

Tepung kacang kedelai digunakan dalam pembuatan fit bar sebagai bahan pengikat, bisanya produk fit bar diolah dengan penambahan tepung terigu sebagai bahan pengikatnya. Tetapi pada penelitian kali ini, bahan pengikat yang digunakan merupakan tepung kedelai dikarenakan tepung kedelai memiliki kandungan protein yang tinggi dibandingkan dengan tepung terigu. Protein pada tepung kedelai dapat mengikat air yang terdapat dalam bahan. Karena menurut Sipahelut (2012), protein akan memiliki titik isoelektrik yang berbeda-beda, sehingga campuran protein tersebut akan memiliki muatan yang bervariasi pula dan dapat mengikat air pada bahan.

\section{Bahan dan Metode Penelitian}

Bahan yang digunakan dalam pembuatan Fit bar Black Mulberry (Morus nigra) adalah buah Black Mulberry (Morus nigra) yang didapatkan dari
Perkebunan Cibodas Maribaya, oat, madu, CMC dan tepung kedelai yang masing didapatkan dari PD. Kijang Mas. Bahan lain yang penting dalam percobaan, antara lain aquadest, larutan $\mathrm{H}_{2} \mathrm{SO}_{4}$, larutan $\mathrm{NaOH}$, larutan $\mathrm{HCl}$, methanol, dan larutan 1,1-difenil-2-pikrilhidrazil (DPPH). Penelitian dilakukan di Laboratorium Teknologi Pangan Universitas Pasundan, Bandung.

Penelitian pendahuluan dilakukan untuk mengetahui konsentrasi penambahan CMC yang tepat dalam pembuatan Fit bar Black Mulberry yang dilihat dari respon organoleptik yang melibatkan 30 orang panelis dengan menggunakan uji hedonik terhadap warna, rasa, dan tekstur.

Penelitian utama yang dilakukan yaitu membuat Fit bar Black Mulberry (Morus nigra) dengan penambahan CMC terpilih dari hasil penelitian pendahuluan dan penambahan bubur buah serta tepung kedelai dengan konsentrasi yang berbeda-beda, kemudian dilakukan rancangan perlakuan, rancangan percobaan, rancangan analisis, dan rancangan respon.

Rancangan Perlakuan yang akan dicobakan pada penelitian utama terdiri dari 2 (dua) faktor, yaitu bubur buah (A) dan tepung kedelai (B), masing-masing terdiri dari 3 (tiga) taraf : taraf faktor A (bubur buah) yaitu $\mathrm{a}_{1}$ $(5 \%), \mathrm{a}_{2}(10 \%), \mathrm{m}_{3}(15 \%)$ dan taraf faktor $\mathrm{B}$ (tepung kedelai) yaitu $b_{1}(14 \%), b_{2}(16 \%)$ dan $b_{3}(18 \%)$.

Rancangan percobaan yang dilakukan adalah rancangan acak kelompok (RAK) dengan pola faktorial 3 x 3 dimana masing-masing rancangan terdiri dari 2 (dua) faktor dengan 3 (tiga) kali ulangan, sehingga didapatkan 27 satuan percobaan.

Respon fisik yang ditentukan adalah mengetahui kekerasan. Respon kimia yang ditentukan adalah kadar karbohidrat menggunakan metode Luff Schoorl, kadar protein menggunakan metode Kjedahl, kadar lemak menggunakan metode Soxhlet, dan aktivitas antioksidan menggunakan metode DPPH. Respon organoleptik dilakukan dengan uji penerimaan (preference test) yaitu uji kesukaan (hedonik) (Soekarto, 1985). Respon yang diuji meliputi warna, rasa, dan tekstur dengan menggunakan 30 orang panelis.

\section{Hasil dan Pembahasan \\ Hasil Penelitian Pendahuluan}

Penelitian pendahuluan dilakukan bertujuan untuk mengetahuipenambahan konsentrasi CMC (Carboxy Methyl Cellulose) yang tepat sehingga dihasilkan tekstur Fit Bar Black Mulberry yang paling baik pada produk serta dapat mewakili produk yang disukai oleh konsumen. Produk yang terpilih diperoleh dari hasil uji organoleptik dengan menggunakan metode uji hedonik yang melibatkan 30 orang panelis serta parameter uji yang digunakan terhadap produk adalah rasa, warna, dan tekstur. 
Tabel 1. Hasil Uji Organoleptik Penelitian Pendahululan

\begin{tabular}{|c|c|c|c|}
\hline \multirow{2}{*}{ Kosentrasi CMC } & \multicolumn{3}{|c|}{ Taraf Nyata } \\
\cline { 2 - 4 } & Tekstur & Warna & Rasa \\
\hline $0,5 \%$ & $2,57(\mathrm{a})$ & $4,87(\mathrm{a})$ & $4,73(\mathrm{a})$ \\
\hline $1 \%$ & $3,87(\mathrm{~b})$ & $5,10(\mathrm{a})$ & $4,53(\mathrm{a})$ \\
\hline $1,5 \%$ & $2,30(\mathrm{a})$ & $4,60(\mathrm{a})$ & $4,70(\mathrm{a})$ \\
\hline
\end{tabular}

Tabel 1. menunjukkan hasil pengamatan uji hedonik terhadap tekstur, warna, dan rasa yang dapat dilihat dari taraf nyata paling diminati oleh konsumen adalah penggunaan CMC pada konsentrasi $1 \%$ dikarenakan dalam segi tekstur perlakuan dengan penambahan CMC sebanyak $1 \%$ paling berbeda nyata dibandingkan dengan penambahan CMC dengan konsentrasi $0,5 \%$ dan $1,5 \%$. Selain itu juga, rata-rata nilai kesukaan dalam hal tekstur, warna, dan rasa jika diakumulasikan memiliki nilai rata-rata tertinggi jika dibandingkan dengan perlakuan penambahan CMC dengan konsentrasi $0,5 \%$ dan 1,5\%. Dapat dilihat pada atribut rasa dan warna tidak menunjukkan adanya perbedaan yang nyata, hal ini dikarenakan konsentrasi penambahan baha-bahan dalam pembuatan fit bar memiliki konsentrasi yang sama tiap perlakuannya, perbedaannya hanya terletak pada penambahan konsentrasi CMC, maka dari itu hanya atribut tekstur saja yang menunjukkan adanya perbedaan.

Tekstur merupakan faktor penting dalam menentukan mutu produk fit bar, karena produk yang baik dapat dilihat secara fisik yaitu fit bar yang memiliki tekstur yang padat serta kokoh, oleh karena itu jika dilihat dari hasil uji organoleptik terhadap sampel dengan konsentrasi CMC 1\% memiliki tekstur yang paling disukai oleh konsumen, sehingga penggunaan CMC sebanyak $1 \%$ akan digunakan dalam penelitian utama.

Tekstur dari fit bar menjadi lebih baik karena adanya penambahan CMC, karena CMC dapat mengikat air atau memberi kekentalan pada fase cair sehingga menstabilkan komponen lain. CMC akan terdispersi dalam air, kemudian butir-butir CMC yang bersifat hidrofilik akan menyerap air dan terjadi pembengkakan. Air yang sebelumnya ada di luar granula dan bebas bergerak, tidak dapat bergerak lagi dengan bebas sehingga keadaan larutan lebih mantap dan terjadi peningkatan viskositas. Terdapat empat sifat fungsional yang penting dari CMC yaitu pengental, stabilisator, pembentuk gel, dan beberapa sebagai pengemulsi (Nugroho (2009), Fennema, Karen, and Lund (1996), Fardiaz (1987) dalam Febriningrum, 2010).

\section{Hasil Penelitian Utama}

Penelitian utama dilakukan untuk mengetahui pengaruh konsentrasi bubur buah dan tepung kedelai serta interaksi antara konsentrasi bubur buah dan tepung kedelai terhadap karakteristik fit bar black mulberry. Penelitian utama menggunakan respon yang diuji yaitu respon organoleptik terhadap rasa, warna, serta tekstur, respon kimia yang meliputi uji kadar karbohidrat, kadar protein, serta kadar lemak, dan respon fisik yaitu analisis kekerasan dengan menggunakan alat penetrometer. Fit bar yang terpilih dilihat dari respon organoleptik, fisika, dan kimia, kemudian tiga produk fit bar terpilih akan dilakukan analisis aktivitas antioksidan dengan menggunakan metode DPPH.

\section{Uji Organoleptik}

a. Rasa

Telah diketahui adanya empat macam rasa dasar, yaitu manis, asin, asam, dan pahit. Konsep empat rasa dasar tersebut sebenarnya hanya merupakan penyederhanaan saja, pada umumnya dikatakan bahwa rasa manis berasal dari senyawa-senyawa gula seperti sukrosa, pahit oleh quinine, asin oleh garam dapur, dan asam oleh asam tartiat dan asam lainnya (Kartika dkk, 1988)

Rasa yang diinginkan dari produk adalah rasa manis karena pada proses pembuatan fit bar black mulberry adanya penambahan madu sebagai penambah rasa manis. Berdasarkan data hasil perhitungan ANAVA, dapat diketahui bahwa faktor A (konsentrasi bubur buah) berpengaruh terhadap karakteristik fit bar black mulberry, tetapi faktor B (konsentrasi tepung kedelai) dan interaksi antara konsentrasi bubur buah dan konsentrasi tepung kedelai tidak berpengaruh terhadap rasa fit bar black mulberry dimana pengaruh tersebut dapat dilihat pada Tabel 2.

Tabel 2. Pengaruh Konsentrasi Bubur Buah Terhadap Nilai Kesukaan Rasa

\begin{tabular}{|l|c|c|}
\hline $\begin{array}{c}\text { Konsentrasi Bubur } \\
\text { Buah }\end{array}$ & Rata-Rata Nilai Kesukaan & Taraf Nyata 5\% \\
\hline a1 (5\%) & 4,06 & a \\
\hline a2 $(10 \%)$ & 4,56 & b \\
\hline a3 $(15 \%)$ & 4,65 & b \\
\hline
\end{tabular}

Keterangan : Nilai rata-rata yang diikuti huruf berbeda, berbeda nyata menurut uji lanjut Duncan pada tarif $5 \%$.

Tabel 2. menunjukkan bahwa rasa fit bar black mulberry pada konsentrasi $5 \%$ berbeda nyata dengan konsentrasi bubur buah pada konsentrasi $10 \%$ dan $15 \%$. Sehingga dapat diketahui bahwa semakin besar konsentrasi penambahan bubur buah, makan semakin tinggi pula penerimaan panelis terhadap rasa fit bar black mulberry. Jika dilihat dari rata-rata nilai kesukaan, fit bar black mulberry dengan konsentrasi bubur buah sebanyak $15 \%$ paling disukai oleh panelis.

Seperti yang diketahui, konsentrasi tepung kedelai tidak berpengaruh terhadap rasa. Karena tepung kedelai tidak memiliki rasa yang khas yang dapat mempengaruhi rasa produk, melainkan bubur buah berpengaruh terhadap rasa dari fit bar black mulberry karena buah black mulberry mengandung 12,9 gram karbohidrat dalam 100 gram bahan, dimana 8,1 gram diantaranya merupakan kandungan gula dan sisanya adalah serat, dengan adanya penambahan buah yang lebih dominan, akan mengakibatkan fit bar dengan kandungan bubur buah paling banyak akan 
menghasilkan produk yang rasanya lebih manis dan paling banyak disukai.

\section{b. Tekstur}

Tekstur merupakan sensasi tekanan yang dapat diamati dengan mulut (pada waktu digigit, dikunyah, dan ditelan) ataupun perabaan dengan jari, dalam pengamatan menggunakan jari akan menimbulkan kesan apakah sesuatu bahan mudah pecah ataupun remuk (Kartika, dkk, 1988).

Tesktur pangan ditentukan oleh kadar air, kadar lemak, dan kandungan struktural seperti selulosa serta protein yang terkandung dalam suatu produk. Protein dapat meningkatkan kemampuan gelasi sehingga dapat membentuk fleksibilitas (Kusharto, 2013). Tekstur memiliki pengaruh penting terhadap produk misalnya dari tingkat kerenyahan, kekerasan, dan sebagainya (Kartika, dkk., 1988).

Data hasil perhitungan ANAVA menunjukkan bahwa faktor A (konsentrasi bubur buah) tidak berpengaruh terhadap karakteristik fit bar black mulberry, tetapi faktor B (konsentrasi tepung kedelai) berpengaruh terhadap tekstur fit bar black mulbeery, sedangkan interaksi antara konsentrasi bubur buah dan konsentrasi tepung kedelai tidak berpengaruh terhadap warna fit bar black mulberry dimana pengaruh tersebut dapat dilihat pada Tabel 3.

Tabel 3. Pengaruh Konsentrasi Bubur Buah Terhadap Nilai Kesukaan Tekstur

\begin{tabular}{|l|c|c|}
\hline $\begin{array}{c}\text { Konsentrasi Tepung } \\
\text { Kedelai }\end{array}$ & Nilai Kesukaan & Taraf Nyata 5\% \\
\hline$b_{1}(14 \%)$ & 3,59 & a \\
\hline$b_{2}(16 \%)$ & 4,44 & b \\
\hline$b_{3}(18 \%)$ & 4,93 & $\mathrm{c}$ \\
\hline
\end{tabular}

Keterangan: Setiap huruf yang sama pada tabel menunjukkan tidak terdapat perbedaan pada taraf $5 \%$.

Tabel 3. menunjukkan fit bar black mulberry dengan konsentrasi tepung kedelai $14 \%$ berbeda nyata dengan fit bar black mulberry dengan konsentrasi tepung kedelai $16 \%$ dan $18 \%$. Semakin banyak kandungan tepung kedelai, semakin tinggi pula nilai kesukaan panelis terhadap tekstur produk. Hal ini disebabkan tepung kedelai memiliki kemampuan dalam mengikat air yang baik karena tepung kedelai memiliki kandungan protein yang tinggi, dimana semakin besar konsentrasi protein maka semakin baik pula terjadinya pengikatan air dalam bahan sehingga semakin banyak tepung kedelai yang ditambahkan semakin baik pula tekstur yang dimiliki oleh produk. Selain itu juga, jika semakin banyak komponen padatan yang ditambahkan pada suatu produk, maka akan dihasilkan produk dengan tekstur yang semakin padat dan kokoh.

c. Warna

Warna penting bagi banyak makanan, baik bagi makanan yang tidak diproses maupun bagi yang dimanufaktur. Bersama-sama dengan bau, rasa, dan tekstur. Warna memegang peranan penting dalam keterimaan makanan. Selain itu, warna dapat memberi petunjuk mengenai perubahan kimia dalam makanan seperti pencoklatan (de Man, 1997).

Warna merupakan atribut fisik yang dinilai terlebih dahulu dalam menentukan mutu makanan. Produk pangan yang bergizi baik terkadang tidak dikonsumsi apabila memiliki warna yang tidak menarik. Berdasarkan hasil ANAVA dapat diketahui bahwa faktor A (konsentrasi bubur buah) berpengaruh terhadap karakteristik fit bar black mulberry, tetapi faktor B (konsentrasi tepung kedelai) dan interaksi antara konsentrasi bubur buah dan konsentrasi tepung kedelai tidak berpengaruh terhadap warna fit bar black mulberry dimana pengaruh tersebut dapat dilihat pada Tabel 4.

Tabel 4. Pengaruh Konsentrasi Bubur Buah Terhadap Nilai Kesukaan Warna

\begin{tabular}{|l|c|c|}
\hline $\begin{array}{c}\text { Konesntrasi Bubur } \\
\text { Buah }\end{array}$ & Nilai Kesukaan & Taraf Nyata 5\% \\
\hline $\mathrm{a}_{1}(5 \%)$ & 3,69 & $\mathrm{a}$ \\
\hline $\mathrm{a}_{2}(10 \%)$ & 4,26 & $\mathrm{~b}$ \\
\hline $\mathrm{a}_{3}(15 \%)$ & 4,94 & $\mathrm{c}$ \\
\hline
\end{tabular}

Keterangan: Setiap huruf yang sama pada tabel menunjukkan tidak terdapat perbedaan pada taraf $5 \%$.

Tabel 4. menunjukkan bahwa warna fit bar black mulberry dengan bubur buah konsentrasi 5\% berbeda nyata dengan konsentrasi bubur buah pada konsentrasi $10 \%$ dan $15 \%$.

Seseorang menilai suatu bahan atau produk pangan yang pertama adalah dilihat dari warnanya. Oleh karena itu, warna pun dijadikan parameter dalam uji kesukaan. Pada awalnya produk fit bar berwarna ungu yang disebabkan adanya penambahan buah black mulberry, yang mana pada buah black mulberry ini mengandung pigmen antosianin yang berwarna keunguan, tetapi setelah dilakukan pemanggangan warna yang dihasilkan berwarna ungu agak keecoklatan, dimana warna fit bar black mulberry yang paling disukai panelis adalah fit bar black mulberry dengan konsentrasi bubur buah $15 \%$.

Fit bar black mulberry mengandung protein dan gula yang berasal dari bahan baku utama dan bahan penunjang yaitu bubur buah dan tepung kedelai, dimana produk ini awalnya berwarna ungu yang diakibatkan pigmen antosianin yang terdapat dalam bahan, tetapi warna produk berubah menjadi berwarna kecoklatan akibat adanya proses pemanggangan, hal ini disebabkan terjadinya reaksi pencoklatan non enzimatis. Menurut Kusnandar (2011), pembentukan warna coklat pada bahan yang dipanggang adalah contoh yang diinginkan dari proses pemanggangan. Pembentukan warna coklat hasil pemanggangan merupakan hasil reaksi Maillard.

Reaksi Maillard merupakan reaksi-reaksi antara karbohidrat, khususnya gula pereduksi dengan gugus amina primer. Hasil reaksi tersebut menghasilkan bahan berwarna coklat (Winarno, 1992).

Suhu pemanggangan pada setiap perlakuan sama yaitu pada suhu $140^{\circ} \mathrm{C}$ selama 30 menit sehingga warna 
pada fit bar black mulberry tidak berbeda nyata pada setiap perlakuannya. Warna pada produk selain sebagai faktor yang menentukan mutu, juga dapat digunakan sebagai indikator baik atau tidaknya pencampuran atau pengolahan yang ditandai dengan adanya warna yang seragam dan merata.

\section{Kekerasan}

Analisis fisik untuk fit bar black mulberry ini menggunakan penetrometer (hardness tester), yaitu suatu alat yang dapat mengukur kekerasan dari tekstur, dimana nilai paling rendah memiliki kekerasan yang paling tinggi.

Berdasarkan hasil ANAVA dapat diketahui bahwa faktor A (konsentrasi bubur buah) berpengaruh terhadap kekerasan, sedangkan faktor B (konsentrasi tepung kedelai) dan interaksi keduanya antara konsentrasi bubur buah dan konsentrasi tepung kedelai tidak berpengaruh terhadap kekerasan fit bar black mulberry, dimana pengaruhnya dapat dilihat pada Tabel 5 .

Tabel 5. Pengaruh Konsentrasi Bubur Buah Terhadap Kekerasan (mm/det/100 gram) Fit Bar Black Mulberry

\begin{tabular}{|c|c|c|c|}
\hline \multirow{2}{*}{$\begin{array}{l}\text { Konseutraai Bubur Buah } \\
\text { (A) }\end{array}$} & \multicolumn{3}{|c|}{ Konsentrasi Tepung Kedelai (B) } \\
\hline & $14 \%\left(b_{1}\right)$ & $16 \%\left(b_{2}\right)$ & $18 \%(b)$, \\
\hline \multirow{3}{*}{$5 \%\left(a_{1}\right)$} & A & A & 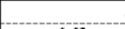 \\
\hline & 1.89 & 1.74 & 1.68 \\
\hline & c & $b$ & $a$ \\
\hline \multirow{3}{*}{$10 \%(2,2)$} & $\bar{E}$ & B & 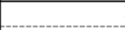 \\
\hline & 2,10 & 2.04 & 2,01 \\
\hline & $c$ & $b$ & 2 \\
\hline \multirow{3}{*}{$15 \%\left(a_{3}\right)$} & c & c & 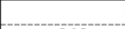 \\
\hline & 2,24 & 2,18 & 2,15 \\
\hline & $b$ & $2 b$ & $a$ \\
\hline
\end{tabular}

Keterangan: Huruf kecil yang berbeda (Horizontal) menunjukan perbedaan yang nyata pada uji Duncan pada taraf 5\%. Huruf besar yang berbeda (Vertical) menunjukan perbedaan yang nyata pada uji Duncan pada taraf $5 \%$.

Respon fisik dan respon organoleptik terhadap tekstur memiliki perbedaan tersendiri dimana pada respon organoleptik diketahui bahwa pada tekstur tidak adanya perbedaan yang nyata pada setiap produk dengan kosentrasi bubur buah dan tepung kedelai yang beragam. Berbeda dengan yang respon fisik dimana setiap produk dengan penambahan konsentrasi bubur buah dan tepung kedelai yang beragam mempunyai perbedaan yang nyata dilihat pada taraf nyata 5\% artinya setiap perbedaan konsentrasi bubur buah dan tepung kedelai yang ditambahkan memberikan pengaruh terhadap kekerasan fit bar black mulberry.

Fit bar dengan konsentrasi tepung kedelai $18 \%$ memiliki kekerasan yang paling baik karena diduga dengan kadar protein yang tinggi cenderung membentuk tekstur yang lebih renyah. Fit bar yang baik seharusnya memiliki kekerasan yang renyah tetapi dengan adanya penambahan bubur buah yang semakin banyak, fit bar yang dihasilkan semakin tidak renyah. Kekerasan didefinisikan sebagai kekuatan atau gaya yang dipelukan untuk mencapai perubahan bentuk. Analisis kekerasan dilakukan karena kekerasan merupakan salah satu kriteria mutu yang paling penting bagi jenis produk sejenis fit bar.
Satuan yang digunakan untuk uji kekerasan adalah mm/detik/100 gram. Artinya angka yang digunakan menunjukan kemampuan penusukan jarum dari alat pengukur untuk menusuk bahan dengan kedalaman tertentu setiap detik. Dengan demikian naiknya angka hasil pengukuran menunjukan turunnya tingkat kekerasan.

\section{Karbohidrat}

Data hasil perhitungan ANAVA terhadap analisis kadar karbohidrat menunjukkan bahwa faktor A (konsentrasi bubur buah), faktor B (konsentrasi tepung kedelai), dan interaksi antara konsentrasi bubur buah dan konsentrasi tepung kedelai berpengaruh terhadap kandungan karbohidrat fit bar black mulberry. Kandungan karbohidrat yang tinggi ini diakibatkan adanya penambahan rolled oat dan penambahan bubur buah black mulberry dengan konsentrasi yang beragam sehingga adanya perbedaan kandungan karbohidrat pada setiap perlakuan, dimana interaksinya dapat dilihat pada Tabel 6.

Tabel 6. Pengaruh Interaksi Antara Konsentrasi Bubur Buah dan Konsentrasi Tepung Kedelai Terhadap Kadar Karbohidrat (\%) Fit Bar Black Mulberry

\begin{tabular}{|c|c|c|c|}
\hline \multirow{2}{*}{ Konsentrasi Bubur Buah (A) } & \multicolumn{3}{|c|}{ Konsentrasi Tepung Kedelai (B) } \\
\hline & $14 \%\left(b_{1}\right)$ & $16 \%\left(b_{2}\right)$ & $18 \%(b)$, \\
\hline \multirow{3}{*}{$5 \%\left(a_{1}\right)$} & & & A \\
\hline & 37.68 & 37,99 & 38,15 \\
\hline & $a$ & $b$ & c \\
\hline \multirow{3}{*}{$10 \%$ (a) } & & & B \\
\hline & 41,12 & 41,90 & 42,32 \\
\hline & $a$ & $b$ & c \\
\hline \multirow{3}{*}{$15 \%$ (a) } & & & $c$ \\
\hline & 42,04 & 42,27 & 43.21 \\
\hline & $\mathrm{a}$ & 6 & c \\
\hline
\end{tabular}

Keterangan: Huruf kecil yang berbeda (Horizontal) menunjukan perbedaan yang nyata pada uji Duncan pada taraf $5 \%$. Huruf besar yang berbeda (Vertical) menunjukan perbedaan yang nyata pada uji Duncan pada taraf $5 \%$.

Buah black mulberry mengandung karbohidrat sebanyak 12,9 gram dalam 100 gram bahan sedangkan tepung kedelai sendiri mengandung karbohidrat kompleks hingga 21 gram dalam 100 gram bahan. Sehingga, produk dengan penambahan konsentrasi bubur buah dan tepung kedelai tertinggi menghasilkan produk dengan kandungan karbohidrat yang paling tinggi jika dibandingkan dengan produk lainnya. Selain itu kandungan karbohidrat yang tinggi ini dikarenakan adanya penambahan rolled oat, dimana rolled oat ini mengandung karbohidrat sebanyak 66,3 gram/100 gram bahan.

\section{Protein}

Data hasil perhitungan ANAVA menunjukkan bahwa faktor A (konsentrasi bubur buah), faktor B (konsentrasi tepung kedelai), dan interaksi antara konsentrasi bubur buah dan konsentrasi tepung kedelai berpengaruh terhadap kadar protein fit bar black mulberry.

Hasil penelitian sebagian besar menunjukkan semakin besar penambahan tepung kedelai maka akan semakin tinggi kadar protein fit bar black mulberry. 
Sampel yang memiliki kandungan protein paling tinggi yaitu sampel $a_{1} b_{3}$ dengan perlakuan penambahan konsentrasi bubur buah sebanyak 5\% dan konsentrasi penambahan tepung kedelai $18 \%$, dimana interaksinya dapat dilihat pada Tabel 7.

Tabel 7. Pengaruh Interaksi Antara Konsentrasi Bubur Buah dan Konsentrasi Tepung Kedelai Terhadap Kadar Protein (\%) Fit Bar Black Mulberry

\begin{tabular}{|c|c|c|c|}
\hline \multirow{2}{*}{$\begin{array}{l}\text { Konsentrasi Bubur } \\
\text { Buah (A) }\end{array}$} & \multicolumn{3}{|c|}{ Konsentrasi Tepung Kedelai (B) } \\
\hline & $14 \%\left(b_{1}\right)$ & $16 \%\left(b_{2}\right)$ & $18 \%\left(b_{i}\right)$ \\
\hline \multirow{3}{*}{$5 \%\left(\mathrm{a}_{1}\right)$} & A & A & A \\
\hline & 7,50 & 8,98 & 11,97 \\
\hline & a & $\mathrm{b}$ & c \\
\hline \multirow{3}{*}{$10 \%(\mathrm{a})$} & $\bar{E}$ & B & $\bar{B}$ \\
\hline & 6,72 & 8,91 & 11,66 \\
\hline & a & $\mathrm{b}$ & c \\
\hline \multirow{3}{*}{$15 \%\left(\mathrm{a}_{\mathrm{A}}\right)$} & c & $\mathrm{C}$ & c \\
\hline & 6,17 & 8,14 & 11,55 \\
\hline & a & $\mathrm{b}$ & c \\
\hline
\end{tabular}

Keterangan: Huruf kecil yang berbeda (Horizontal) menunjukan perbedaan yang nyata pada uji Duncan pada taraf $5 \%$. Huruf besar yang berbeda (Vertical) menunjukan perbedaan yang nyata pada uji Duncan pada taraf $5 \%$.

Sampel $a_{1} b_{3}$ merupakan sampel yang memiliki kandungan protein lebih tinggi dari sampel lainnya, hal ini disebabkan karena formulasi yang digunakan dalam sampel tersebut menggunakan tepung kedelai dengan konsentrasi $18 \%$. Kehilangan protein dapat pula diakibatkan adanya proses pemanasan sehingga sebagian protein yang terkandung dalam produk kemungkinan akan hilang saat proses pengolahan. Selain itu, dikarenakan adanya kandungan asam dari buah black mulberry sebagian kandungan protein yang terdapat dalam bahan pun menjadi hilang diduga karena adanya proses denaturasi protein.

Soy powder banyak digunakan sebagai bahan makanan campuran dalam formulasi suatu bentuk makanan seperti roti, kue kering, donat, dan produk olahan lainnya. Produk olahan dengan bahan makanan campuran tepung kedelai dapat meningkatkan nilai gizi suatu produk (Santoso, 2005).

\section{Lemak}

Data hasil perhitungan ANAVA menunjukkan bahwa faktor A (konsentrasi bubur buah), faktor B (konsentrasi tepung kedelai), dan interaksi antara konsentrasi bubur buah dan konsentrasi tepung kedelai berpengaruh terhadap kadar lemak fit bar black mulberry, dimana interaksinya dapat dilihat pada Tabel 8.

Soy powder mengandung 20,53\% lemak dan oat mengandung $7 \%$ lemak. Sehingga saat keduanya disubtitusi maka akan terjadi perubahan kandungan lemak pada Fit Bar Black Mulberry. Selain itu penambahan lemak dilakukan untuk menambah kalori serta memperbaiki tekstur dan cita rasa bahan pangan. Sampel yang memiliki kandungan lemak paling tinggi yaitu sampel $a_{3} b_{3}$ dengan kadar lemak 9,23 dengan perlakuan penambahan konsentrasi bubur buah sebanyak 5\% dan konsentrasi penambahan tepung kedelai $18 \%$. Semakin banyak konsentrasi tepung kedelai dan bubur buah yang ditambahkan, semakin meningkat juga kandungan lemak pada fit bar black mulberry. Hal ini dikarenakan, tepung kedelai itu sendiri memiliki kandungan lemak yang cukup tinggi, sehingga dapat mempengaruhi total kandungan lemak yang terdpat pda produk.

Namun fit bar black mulberry memiliki kandungan lemak yang kurang dari standar kandungan lemak pada produk sejenis food bar, karena kurangnya bahan yang berpotensi menyumbangkan kandungan lemak pada bahan dan diduga kandungan lemak pada bahan hilang karena adanya proses pemanasan yang dapat menyebabkan kandungan lemak dalam bahan bisa berkurang.

Tabel 8. Pengaruh Interaksi Antara Konsentrasi Bubur Buah dan Konsentrasi Tepung Kedelai Terhadap Kadar Lemak (\%) Fit Bar Black Mulberry

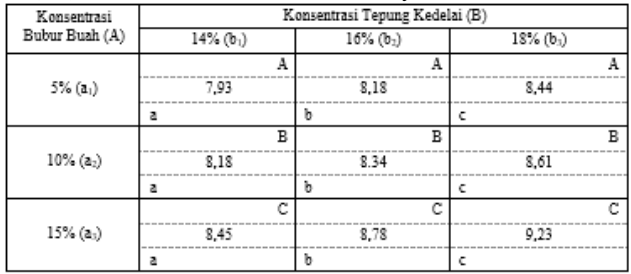

Keterangan: Huruf kecil yang berbeda (Horizontal) menunjukan perbedaan yang nyata pada uji Duncan pada taraf $5 \%$. Huruf besar yang berbeda (Vertical) menunjukan perbedaan yang nyata pada uji Duncan pada taraf $5 \%$.

\section{Pengambilan Produk Terpilih}

Berdasarkan hasil respon kimia yaitu kadar karbohidrat, lemak, dan protein, respon fisika yaitu kekerasan, serta respon organoleptik dengan menggunakan uji hedonik terhadap warna, rasa, dan tekstur pada penelitian utama, maka diperoleh produk terbaik yaitu sampel $a_{1} b_{2}$ (konsentrasi bubur buah $5 \%$ dan tepung kedelai 16\%), $a_{3} b_{1}$ (konsentrasi bubur buah $15 \%$ dan tepung kedelai $14 \%$ ), dan $\mathrm{a}_{3} \mathrm{~b}_{3}$ (konsentrasi bubur buah $15 \%$ dan tepung kedelai $18 \%$ ) yang dapat dilihat pada Tabel 9. Perlakuan terbaik yang dipilih mengacu pada karakteristik fit bar black mulberry yang diinginkan.

Tabel 9. Nilai Akumulasi Fit Bar Black Mulberry (Produk Terbaik)

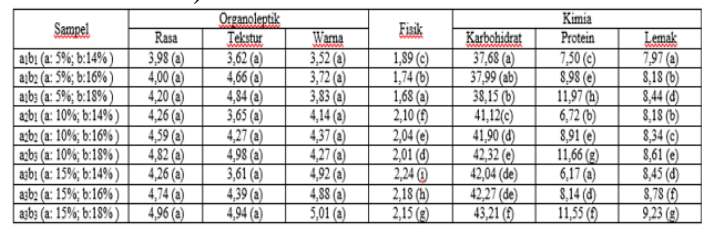

Keterangan: Setiap huruf yang sama pada tabel menunjukkan tidak terdapat perbedaan pada taraf $5 \%$.

Berdasarkan Tabel 9, hasil penelitian utama dengan pengaruh konsentrasi bubur buah $(5 \%, 10 \%$, dan $15 \%)$ dan konsentrasi tepung kedelai $(14 \%, 16 \%$, dan $18 \%$ ) terhadap masing-masing respon yakni perlakuan $\mathrm{a}_{1} \mathrm{~b}_{2}$ (Konsentrasi bubur buah 5\% dan konsentrasi tepung kedelai $16 \%$ ), $\mathrm{a}_{3} \mathrm{~b}_{1}$ (Konsentrasi bubur buah $15 \%$ dan konsentrasi tepung kedelai 14\%), dan $a_{3} b_{3}$ (Konsentrasi bubur buah $15 \%$ dan konsentrasi tepung 
kedelai 18\%) merupakan sampel terpilih, dimana sampel terpilih tersebut akan dilakukan analisis aktivitas antioksidan menggunakan metode DPPH.

\section{Protein}

Tingkat kekuatan antioksidan senyawa uji menggunakan metode DPPH dapat digolongkan menurut $\mathrm{IC}_{50}$. Semakin kecil nilai $\mathrm{IC}_{50}$ berarti semakin tinggi aktivitas antioksidannya (Zuhra, 2008).

Tabel 10. Tingkat Kekuatan Antioksidan dengan Metode DPPH

\begin{tabular}{|l|l|}
\hline \multicolumn{1}{|c|}{ Intensitas } & \multicolumn{1}{c|}{ Nilai IC $_{50}$} \\
\hline Sangat kuat & $<50 \mathrm{ppm}$ \\
\hline Kuat & $50-100 \mathrm{ppm}$ \\
\hline Sedang & $101-150 \mathrm{ppm}$ \\
\hline Lemah & $>150 \mathrm{ppm}$ \\
\hline
\end{tabular}

(Zuhra, dkk., 2008)

Suatu zat mempunyai sifat antioksidan bila nilai $\mathrm{IC}_{50}$ yang diperoleh berkisar antara 200-1000 $\mu \mathrm{g} / \mathrm{mL}$, dimana zat tersebut kurang aktif namum masih berpotensi sebagai zat antioksidan (Molyneux (2004) dalam Batubara, 2015).

Nilai $\mathrm{IC}_{50}$ didefinisikan sebagai besarnya konsentrasi senyawa uji yang dapat meredam radikal bebas sebanyak 50\%. Semakin kecil nilai IC50 maka aktivitas peredaman radikal bebas semakin tinggi. Prinsip kerja dari pengukuran ini adalah adanya radikal bebas stabil yaitu DPPH yang dicampurkan dengan senyawa antioksidan yang memiliki kemampuan mendonorkan hydrogen, sehingga radikal bebas dapat diredam (Zuhra, dkk. 2008). Hasil analisis aktivitas antioksidan dari fit bar black mulberry

Tabel 11. Hasil Analisis Aktivitas Antioksidan Terhadap Fit Bar Black Mulberry

\begin{tabular}{|c|c|}
\hline Perlakuan & ppm \\
\hline $\mathrm{a}_{3} \mathrm{~b}_{1}$ & 190,342 \\
\hline $\mathrm{a}_{1} \mathrm{~b}_{2}$ & 146,151 \\
\hline $\mathrm{a}_{3} \mathrm{~b}_{3}$ & 139,480 \\
\hline
\end{tabular}

Data pada Tabel 11 menunjukkan bahwa sampel $\mathrm{a}_{3} \mathrm{~b}_{3}$ merupakan sampel terpilih dikarenakan memiliki aktivitas antioksidan paling rendah dibandingan dengan sampel $a_{1} b_{2}$ dan $a_{3} b_{1}$ yaitu dengan aktivitas antioksidan sebesar 139,480 ppm, yang artinya sampel fit bar black mulberry memiliki kemampuan yang sedang dalam meredam radikal bebas.

Berdasarkan hasil penelitian, dapat diambil kesimpulan sebagai berikut :

1. Konsentrasi bubur buah berpengaruh nyata terhadap warna, rasa, kadar karbohidrat, kadar protein, kadar lemak, dan kekerasan pada fit bar black mulberry.

2. Konsentrasi tepung kedelai berpengaruh terhadap tekstur, kan dari kadar karbohidrat, kadar protein, kadar lemak, dan kekerasan pada fit bar black mulberry.

3. Interaksi antara konsentrasi bubur buah dan konsentrasi tepung kedelai berpengaruh nyata terhadap respon kimia meliputi kadar karbohidrat, kadar protein, dan kadar lemak, maupun respon fisika yaitu kekerasan pada fit bar black mulberry.

\section{Daftar Pustaka}

1. Anonim, 2015. Morus (Plant), <https://en.wikipedia.org>, diakses: 12 Mei 2016.

2. deMan.J.M, 1997. Kimia Makanan, Edisis Ke-2. Terjemahkan Kosasih Padmawinata. ITB, Bandung.

3. Febriningrum, Fitriana. 2010. Pembuatan Edible Film dari Pati Kimpul. Skripsi Fakultas Teknologi Industri UPN "Veteran" Jawa Timur.

4. Kartika, Bambang. 1988. Pedoman Uji Inderawi Bahan Pangan. UGM. Yogyakarta.

5. Kusnandar, F. 2011. Kimia Pangan Komponen Makro. Dian Rakyat. Jakarta.

6. Santoso, S. P. 2005. Teknologi Pengolahan Kedelai. Fakultas Pertanian Universitas Widyagama. Malang.

7. Sipahelut, S. G., 2012. Protein (Kimia Pangan dan Hasil Pertanian, <http://www.slideshare.net>, diakses: 13 Maret 2016.

8. Soekarto, T. Soewarno. 1985. Penilaian Organoleptik. Bhatara Karya Aksara, Jakarta

9. Widiyantoro, A. dan Pratama, N. 2014. Murbei/Mulberry <http://ccrc.farmasi.ugm.ac.id>, diakses: 13 Maret 2016.

10. Winarno, F.G. 1992. Kimia Pangan dan Gizi. Gramedia Pustaka Utama : Jakarta.

11. Zuhra, dkk. 2008. Aktivitas Antioksidan Senyawa Flavonoid Dari Daun Katuk (Sauropus androgonus (L) Merr.). Jurnal Biologi Sumatera Vol. 3, No. 1. 